\title{
Defense System, Industry and Academy: The Conceptual Model of Innovation of the Brazilian Army
}

\author{
Marcus Vinicius Gonçalves da Silva ${ }^{1 *}$; Carlos Olavo Quandt ${ }^{2}$
}

\begin{abstract}
This article intends to identify the technological parks existing in the headquarters of military regions of the Brazilian Army, with the premise that these habitats are capable of forming nuclei of governance of technological innovation. The problem is that since the year of 2016 , the Brazilian Army created the Defense, Industry and Academy System (SisDIA) of Innovation, a conceptual model of the Triple-Helix, aiming to promote the development of innovations taking advantage of the Army presence in all regions of the country. For that, methodologically, it was chosen to conduct a research with an exploratory, qualitative and descriptive approach, and the case study of the Brazilian Army. It was possible to conclude that through SisDIA and the implantation of governance nuclei of innovation in the Brazilian Army, inserted in technological parks, there will be a possibility of interaction between the Triple-Helix (government-industry-academy), in a collaborative way, intending to reinforce the scientific and technological expression of the actors involved and to boost the development in social and economic dimensions according to regional potentialities.
\end{abstract}

Keywords: innovation ecosystems; triple-helix; technological parks; governance; Brazilian Army

Submitted: Jun 10 $0^{\text {th }}, 2018 /$ Approved: March $22^{\text {nd }}, 2019$

\section{Introduction}

Promoting the development of innovations has shown a perennial challenge to public and private organizations, in a way that the access and perspective of the gains in innovation are increasingly been inserted in the national and international scenarios. The innovative process is a boost for business growth and increases competitiveness. The search for environments that provide an opportunity to implement new products and services or spaces to access scientific knowledge and technology is becoming paramount.

The institutional spaces of development of innovative enterprises are usually called innovation habitats. Technological Parks (TPs) are favorable environments that have a fundamental role in the economic development, being favorable places to exchange knowledge, practices of production and the development of relationships among entrepreneurs of innovation, be they governmental, educational or from companies. Similarly, it is stated that they may arise in the institutionalization of Triple-Helix (TH) according to Henry Etzkowitz and Loet Leydesdorff (2000) writings, when they describe a relationship between government, industry and academia (G-I-A).

For a TPs to carry out its functions in order to respond to the requirements of its respective participations, it is mandatory to have a consolidation of good governance practices. Based on its principles and concepts, such practices include the technology sector, a knowledge-promoting initiative, entrepreneurs, government and cooperation among stakeholders.

Given this initial context, this work is justified by the possibility of contributing to studies on the management of innovation in the military area, with the case of the Brazilian Army, due to its strategic nature, and to demonstrate that military innovation can contribute to local and regional development, through technological innovations and the production of military employment material, as well as allowing these innovations to foster the national defense industry.

It is also verified, in a seminal form, that there is a need to propose a model of governance structure of technological innovation for the Brazilian Army, due to the Brazilian territorial extension and its role in economic, urban and regional development, aligned with promotion of its strategic capacity and the institutional vision of acting on the frontier of dual technology and open innovation.

Therefore, it is of interest: How can the model of the Triple-Helix, implemented by the Brazilian Army, called SisDIA, contribute to the structure and the promotion of innovation in defense of existing habitats in the headquarters of Military Regions? To answer this question, a survey was made in the literature and on the concepts of technological parks, concepts of governance and networks of governance. This survey provided the theoretical support for the purpose of this work.

The article is divided into four sections. In addition to this introduction, section 2 presents the methodological aspects; section 3 reviews the literature on innovation ecosystems, technology parks, governance concepts, and networks. The section 4 describes the System of Science and Technology and Innovation of the Brazilian Army (SCTIEx) and its structure; and in the section 5, a model is proposed for structuring a Nucleus of Governance of Technological Innovation of the Army. Finally, the section 6 presents the final considerations of the article.

(1) Administration Postgraduate Program, Pontifical Catholic University of Paraná, Curitiba, Paraná, Brazil.

(2) Pontifical Catholic University of Paraná, Curitiba, Paraná, Brazil.

*Corresponding author: marvin.gsilva@gmail.com 


\section{Method}

The method used, in consonance with the taxonomy used by Vergara (2004), was based on two criteria: the purposes and the means. As for the purposes, the research can be classified as exploratory, once the proposal of a governance of innovation model for the Brazilian Army, from a perspective of concepts of Innovation Ecosystems (IE) and Triple-Helix (HT), in addition to never being published; it lacks an initial base and subsequent theoretical-applied deepening. As for the means, the investigation has a documental approach, developed by analysis of reports and studies published at the website from the Ministry of Science, Technology Innovation and Communications (MCTIC), the International Association of Science Parks and Areas of Innovation (IASP) and the National Association of Entities that Promote Innovative Enterprises (Anprotec), besides the institutional documents of the Brazilian Army that did not receive a analytic treatment, as for the legal rules and regulation activities of innovation and technology from the Brazilian Army. Aiming to find the answer for the problem-question of the research the case study strategy was chosen. In this paper, the case analyzed was that of the headquarters of the Military Regions of the Brazilian Army and a survey of the Technological Parks existing in these headquarters, intending to verify the potentialities of these innovation habitats and the implementation of Nucleus of Governance of Technological Innovation, in particular, in the city of Curitiba, as for the possibility of these authors to carry out the research by a direct and participative observation.

\section{Innovation Habitats}

Innovation habitats are environments that offer incentives for entrepreneurial development in the various phases of the company, since the begining until the consolidation of a large organization focused on technology and innovation. Entrepreneurs seek these environments to establish cooperation with universities and research centers, sharing knowledge and developing innovation projects. Habitats consist of pre-incubators, business incubators and technology parks.

Specifically, the focus of this study will be the Technology Parks (TPs), with the premise, and according to the literature researched, that these innovation habitats are the most favorable to create interaction between universities, companies, development agencies and the government.

The International Association of Science Parks (IASP, 2010) defines technology parks as an organization managed by specialized professionals, with the fundamental objective of increasing the wealth from its community by promoting the culture of innovation and the competitiveness of companies and institutions that generate knowledge.

Based on the interaction between universities and the private enterprise, technology parks aim to promote a technical, logistical and administrative infrastructure to help companies develop their products, increase competitiveness and favor technological transference and the creation of a proper environment to innovation (Bakouros, Mardas \& Varsakelis, 2002).
Therefore, the focus of PqTs is to stimulate the economy based on knowledge, creating a synergistic environment and confiability between universities and businesses in order to increase the possibilities of flow between knowledge assets (Labiak Junior \& Gauthier, 2010). In this perspective, the TPs located in several regions of the country and, in areas near universities and research centers, aim the implementation of infrastructure for research laboratories, services and support to companies in the process of technological development and innovation.

\section{Contribution of Technology Parks in the formation of Inno- vation Ecosystems}

Innovation ecosystems (EI) are characterized as proper environments to entrepreneurship, through the continuous development of innovations, spaces for collective learning, exchange of knowledge and productive practices, and of synergy between the various agents of innovation (Spinosa et al, 2015).

Recently, the Decree 9.283, of February 7, 2018, conceptualized the IE as

[...] spaces that add infrastructure and institutional and cultural arrangements that attract entrepreneurs and financial resources are places that enhance the development of the knowledge society and include, among others, science and technology parks, smart cities, innovation districts and technological poles (Brazil, 2018).

Over the time, poles and technology parks have been presented as important tools for boosting developed economies, and also the ones in development, following the success of experiments such as Sillicon Valley in California and Route 128 in Massachusetts in USA. Something that is common to the PqTs is the presence of several agents represented by the tripod: government, industry and academia (G-IA) in intense interaction.

The Route 128, near Boston, still remains as the unifying element for GIAs in the region, particularly at the Massachusetts Institute of Technology (MIT) and at Harvard University. As pointed out by Dorfman (1983, in Barbieri, 1995) this cluster emerged spontaneously, unlike the Sillicon Valley that was carefully nurtured by Stanford University under the leadership of Frederick Terman in the early 1950s.

Among the factors that contributed to the formation of the cluster of technology-based defense companies around Route 128, besides the availability of highly qualified human resources by local GIAs and technological infrastructure, the existence of venture capital in abundance in the region was preponderant in the Boston area (Dorfman, 1983 in Barbieri, 1995).

It should be highlighted that the experiences of Silicon Valley and Route 128 promoted the idea of technological parks as inductors and facilitators in the formation of innovation ecosystems through the interaction between the Triple-Helix researches (government-industry- 
academia) and the needs of the productive and governmental sectors. Despite their diverse names - technology centers, high technology centers, hatcheries, techno parks or scientific cities, science and technology parks - or simply technology parks, this habitat seeks to foster technology transference and innovation, competitiveness of compa- nies, regions and even nations (Hassink \& Hu, 2012). The definition, objectives, as well as the advantages and disadvantages of Technological Parks were synthesized and compiled in Table 1, according to data from IASP (2010) and Do Nascimento and Labiak Junior (2011) studies.

Table 1. Characteristics of Technologic Parks. Adapted from IASP (2010) and Do Nascimento and Labiak Junior (2011).

\begin{tabular}{|c|c|c|}
\hline & Definition & Objectives \\
\hline $\begin{array}{c}\text { Technologic } \\
\text { Parks }\end{array}$ & $\begin{array}{l}\text { An organization managed by specialized professionals, with the } \\
\text { fundamental objective of increasing the wealth of its communi- } \\
\text { ty by promoting a culture of innovation and competitiveness of } \\
\text { companies and institutions that generate knowledge [...] (IASP, } \\
2010) \text {. }\end{array}$ & $\begin{array}{l}\text { Act like a link between the university and the companies located in the } \\
\text { park. } \\
\text { Bring together entrepreneurs and researchers and generate knowledge } \\
\text { flow among these agents. } \\
\text { Connect entrepreneurs and students with the potential to work in the } \\
\text { park companies, due to their proximity to universities. } \\
\text { To house companies in harmony with the environment, generating little } \\
\text { or no waste. } \\
\text { Influence the region where it is located, through the development of the } \\
\text { economy based on knowledge. }\end{array}$ \\
\hline
\end{tabular}

Advantages

* Stimulate social and collective awareness of the importance of technology and innovation.

* Work with network concept.

* Encouraging quality culture in the global management of enterprises.

* Possibility of access to a vast network of contacts, including international ones.

* Contact with people of high added value, interested in generating synergy for innovation.

\section{Disadvantages}

${ }^{*}$ In some cases, interaction with universities is less than desirable.

* Some parks have an excessively "real estate" aspect, not enhancing the integration with the other actors of the park, such as universities and research centers.

${ }^{*}$ Limited presence of development agents or venture capitalists.

In relation to the objectives, it is emphasized that the training of the human resources that work in the companies located in the TPs is a competitive differential, especially when it is considered that initiatives directed to technological innovation do not dismiss professionals that support the technical development of the companies (MCTI, 2004). In table 2 it is possible to identify some supports offered by the Technology Parks.

Table 2. Supports offered by Technology Parks. Elaborated from IASP (2010) and Do Nascimento e Labiak Junior (2011).

Consulting and services in the areas of business management

Advising of processes to encourage innovation.

Access to park network and partners.

Links with international parks networks.

Provision of resources through funds or special lines of financing.

Proximity with funds from Venture Capital and Angel Investments.

Assistance in the structuring of projects for the use of governmental tax incentives and fundraising.
Guidelines on Intellectual Property.

Assistance in communication and marketing projects.

Access to training in foreign languages, courses in Innovation Management, among others, with differentiated costs.

Organization of business rounds.

Support for the internationalization of business.

Physical infrastructure: auditoriums, meeting rooms and videoconferencing, Internet (fiber optics), restaurants, living environment, banks, among others.

Urban parks in areas with municipal tax and tax incentives, such as reduction of ISS, IPTU and ITBI.

Safe environment. 
With the support offered by the TPs, the companies remain connected with opportunities for development existing in the country, made available in public notices, and integrate part of a network of competitive companies that develop innovations in a cooperative way.

\section{Concepts, Structure and Models of Governance}

The concept of governance refers to the different ways in which individuals and organizations (public and private) manage their common issues, adjusting conflicting or distinct interests through cooperative actions (Cassiolato \& Lastres, 2003). Governance can also be characterized by an institutional coordination process, consisting of formal and/or informal mechanisms, providing solutions to problems that go beyond the limits of economic relations (Menezes \& Vieira, 2011).

In this study, the governance concept of Suzigan et al. (2007) was adopted, as the capacity of command or coordination that agents or institutions exert over productive, commercial, technological and other interrelationships, decisively influencing the development of the local system or arrangement.

Regarding the definition of governance structure, Buainain et al. (1999) describe it as a set of organizational forms that condition the relationship between agents that are engaged in an activity, determining individual incentives and allocating available resources.

The governance structures vary depending on the type of production system in each region. This, by its turn, is determined by the structure of production, agglomeration of companies, coordination among agents, penetration of industries in the market, institutional density and the social tissue of the region (Suzigan et al., 2007).

Storper and Harrison (1991) associate these governance structures of productive agglomerations to the degree of hierarchy, leadership and command (or collaboration and cooperation) exercised by the firms in the coordination of these relations with other companies participating in the system.

In the context of the innovations, Carvalho, Cavalcante and Reis (2009) point out three internal elements of the organizations that make it possible to take advantage of these opportunities: i) the environment conducive to innovation; ii) creative people (entrepreneurs, contributors and employees), prepared and stimulated to innovate; and, iii) the systematic and continuous process (or method) of innovation. It is noted that in all these elements people are considered the fundamental element.

However, other assets have an important contribution to the capacity of innovation, such as public policies, investments and incentives of the government, articulation between associations and federations of companies, opening of universities and institutes to create partnerships to finance and foster innovation (Carvalho, Cavalcante \& Reis, 2009). Thus, intersectoral partnerships have several denominations. Some authors call these partnerships as intersectorial collaborations (Bryson, Crosby \& Stone, 2006); collaborative public management (McGuire, 2006); collaborative governance (Ansel \& Gash, 2008); or intersectorial partnerships to address social issues (Selsky \& Parker, 2005).
Collaborative governance, by its turn, became a reference for studies on collaborative public management, government networks, multiparty governance and hybrid sectorial arrangements (Ferreira, 2015). The collaborative governance model proposed by Ansell and Gash (2008) is an analytical framework based on a contingency approach that aims to provoke the questioning of contextual conditions, that is, whether they facilitate or discourage the results of the partnership.

According to Cabral, Krane and Dantas (2013), the governance model proposed by Ansell and Gash (2008) is one of the most accepted in the literature and suggests that some factors influence the collaborative process, in other words:

Firstly, there is the importance of the initial conditions for collaboration, which encompasses the prehistory of cooperation and the asymmetries of power, resources and knowledge between the parties, which together shape the incentives and constraints for participation.

In parallel, there is the institutional design that surrounds the collaborative process composed of the rules of participation, conditions of inclusion of actors, as well as aspects related to the accountability of the agents and transparency of the collaborative process.

A third relevant component is the presence of facilitating leadership so that the various stakeholders can commit to interorganizational collaboration (Cabral, Krane \& Dantas, 2013, pp. 14748, emphasis added).

These three components feed into the collaborative process itself, within which a cycle is initiated by face-to-face dialogues, which in its turn stimulate the building of the mutual trust necessary for the commitment of the various stakeholders to the process of collaboration and the shared understanding of the missions, problems and common values, which lead to small intermediate victories capable of reinforcing the cycle of the cooperation process, until the final result of collaborative governance is obtained.

The collaborative process encourages the building of the mutual trust necessary for the commitment of the various stakeholders to the process of collaboration and the shared understanding of the missions, problems and values in common, which lead to small intermediate victories capable of reinforcing the cycle of the collaborative process until the final result of collaborative governance is achieved (Cabral, Krane \& Dantas, 2013).

With decisions taken in a shared way, the governance of multiple organizations engaged in collaborative processes is characterized by the intense participation of its members, depending almost exclusively on the involvement and commitment of their components, even though they have different characteristics. 


\section{The Brazilian Army's Science, Technology and Innovation System}

The vision of the Brazilian Army (BA) that integrates the Terrestrial Military Policy, projects that by the year 2022 a new doctrine will be reached - with the use of technologically advanced defense products, highly trained and motivated professionals - so that the Army, with appropriate tools, faces the challenges of the 21st century, supporting the sovereign decisions of Brazil in the international arena (Brazil, 2013).

The need to implement a new and effective Brazilian Army Science, Technology and Innovation System (SCTIEx) is based on two concepts: i) that the current system does not favor the generation of innovations, in the quality and quantity demanded by the Army Transformation Process; and, ii) the indication that the current model "directs the System's effort, in a prevailing way, to meet the current needs of the Army, with little adherence to the PD \& I cycle" (Brazil, 2012, p. 32). In a study by Prado Filho (2014), the author points out that the lack of alignment of these conceptions has caused a mismatch between the expectations of the Brazilian Army and the deliveries of the products in the System.

In BA, the Triple-Helix of SCTIEx was structured according to the statist model of Etzkowitz and Leydesdorff (2000), and the government, represented by the Brazilian Army, through the Department of Science and Technology (DCT); the industry, represented by the Military War Industry (IMBEL); and the academy, represented by the Military Engineering Institute (IME). Figure 1 illustrates the composition of this model.

Figure 1: Triple-Helix of SCTIEx (Statist Model). Author's elaboration.

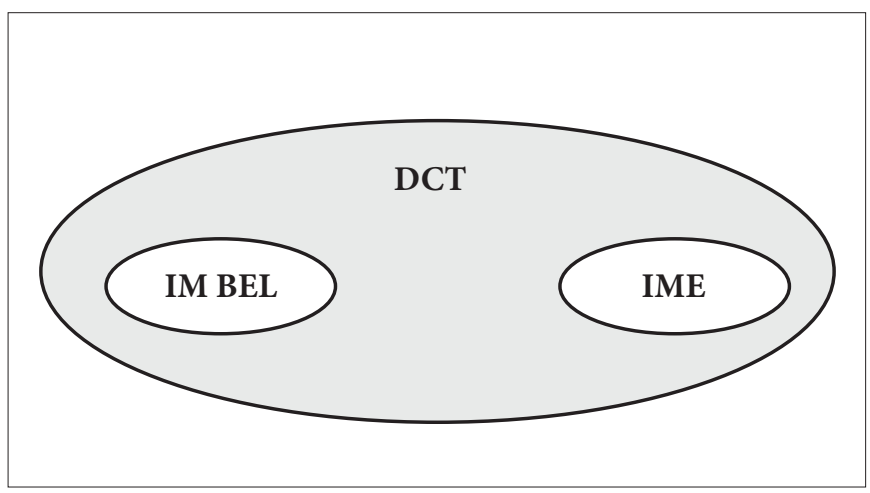

With the new SCTIEx, the organizational characteristics will be presented as effectively innovative, integrated with the internal and external environments to the Army, oriented to the future, with emphasis on results, and fully aligned with the needs of the Terrestrial Force (Brazil, 2012). In the model of the Triple-Helix, called balanced (Etzkowitz \& Leydesdorff, 2000), institutions are more autonomous, making relations more symmetrical, reciprocal and cooperative, that is, the limitations of each of the actors can be suppressed or softened by the other, making it extremely healthy for the creation of new development strategies and innovation practices.

\section{The Brazilian Defense System, Industry and Academy System}

The Brazilian Army has sought its modernization and transformation to raise higher altitudes, and it is becoming obvious that it is necessary to reduce, if not neutralize, the technological differences that lead to relevant disadvantages to the maintenance of national interests.

In order to achieve its objectives, the Army, in 2016, through its Department of Science and Technology (DCT), established the Defense System, Industry and Academia (SisDIA) of Innovation, with a national scope, aiming to increase cooperation between these areas, acting in the promotion of actions that aim the generation of opportunities for the development of brand new technologies for the Defense Area with dual technology applicability (DCT, 2017).

Figure 2. SisDIA of Innovation from Brazilian Army (Logo). DCT (2018).

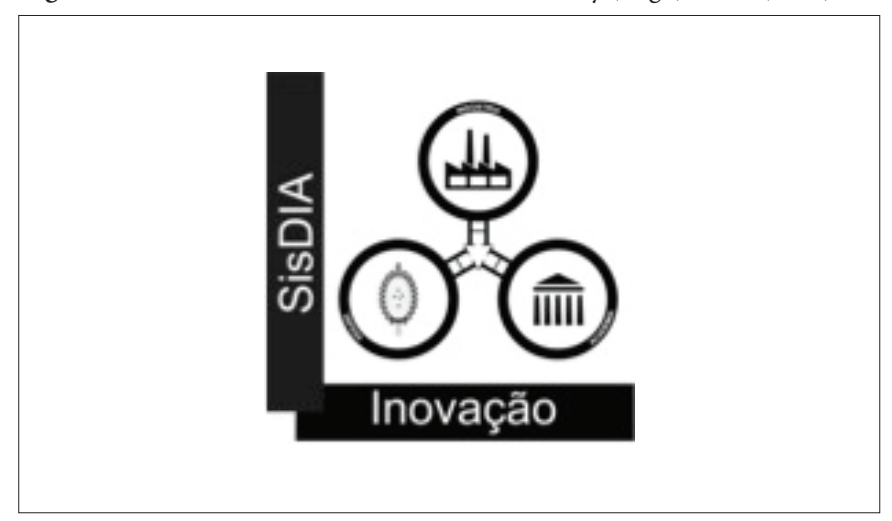

In order to achieve the National Defense goals for innovation and technology, SisDIA will act according to the levels presented in Table 3.

Table 3. Levels of SisDIA performance. Data from DCT (2018).

\begin{tabular}{lll}
\hline Local level & Regional level & National level \\
\hline $\begin{array}{l}\text { Execution of Army projects and/or contributes to } \\
\text { Local Productive Arrangements (LPAs). }\end{array}$ & $\begin{array}{l}\text { Operational strategic level, which stimulates the regional } \\
\text { potential of industrial and academic propellers. }\end{array}$ & $\begin{array}{l}\text { Strategic level, which focuses on the efforts of } \\
\text { the government propeller sectors. }\end{array}$ \\
$\begin{array}{l}\text { Actors: BA, Industries, Universities, Poles or } \\
\text { Parks of S\&T, Incubators of companies and LPAs. }\end{array}$ & Actors: BA, Federations of Industries, SENAI, Universities & Actors: BA, Ministries, National Confedera- \\
Operational performance. & Strategic-operational performance. & tion of Industries, Development Agencies. \\
Execution of projects & Meetings, seminars, visits. & Political action. \\
Best characterization of the Triple-Helix. & Technological prospecting. & Meetings, seminars, visits. \\
& Identification and support for possible LPAs. & Identification of opportunities. \\
& Identification of partners to receive technology. & \\
\hline
\end{tabular}


Regarding the performance levels, some gaps can be observed and deserve to be highlighted, such as the lack of prediction and implementation of public innovation policies in the three spheres of government, and the definition of a governance model to structure the interaction between the various actors.
It is noted that with SisDIA, it will be possible to implement nuclei of technological innovation governance throughout the national territory, to benefit the socioeconomic potential of each region and the presence of Technology Parks. At Table 4 it is listed the host cities and states of jurisdiction in the twelve military regions of the Brazilian Army.

Table 4. Military Regions under the jurisdiction of the Brazilian Army. Data from Brazil (1999).

\begin{tabular}{|c|c|c|c|c|c|}
\hline Military Region & Headquarters & $\begin{array}{c}\text { Jurisdiction } \\
\text { (Units of the Federation) }\end{array}$ & Military Region & Headquarters & $\begin{array}{c}\text { Jurisdiction } \\
\text { (Units of the Federation) }\end{array}$ \\
\hline 1 st & Rio de Janeiro & $\begin{array}{l}\text { Rio de Janeiro e } \\
\text { Espírito Santo }\end{array}$ & 7 th & Recife & $\begin{array}{c}\text { Alagoas, Pernambuco, } \\
\text { Paraíba e Rio Grande do Norte }\end{array}$ \\
\hline 2nd & São Paulo & São Paulo & 8th & Belém & Pará e Macapá \\
\hline $3 \mathrm{rd}$ & Porto Alegre & Rio Grande do Sul & 9th & Campo Grande & $\begin{array}{c}\text { Mato Grosso do Sul e Mato } \\
\text { Grosso }\end{array}$ \\
\hline 4 th & Belo Horizonte & Minas Gerais & 10 th & Fortaleza & Ceará, Piauí e Maranhão \\
\hline 5 th & Curitiba & Paraná e Santa Catarina & 11 th & Brasília & $\begin{array}{c}\text { Distrito Federal, Goiás e To- } \\
\text { cantins }\end{array}$ \\
\hline 6 th & Salvador & Bahia e Sergipe & 12 th & Manaus & $\begin{array}{l}\text { Amazonas, Acre, } \\
\text { Roraima e Rondônia }\end{array}$ \\
\hline
\end{tabular}

These military regions are commanded by General Officers, and are located in the main Brazilian capitals, revealing a factor that may impact integration with the various actors of the IE, since one of the duties of the Military Regions is to carry out, according to institutional guidelines of the Army, studies and experiments, aiming at the doctrinal improvement in the area of defense (Brazil, 1977, emphasis added).

In this context, it is argued that the Regional Commands are competent units to mediate the actions proposed by the Brazilian Army's
Science, Technology and Innovation System (SCTIEx). The results presented by the Ministry of Science, Technology, Innovation and Communications, in 2014, indicate that there is a positive relationship between the number of parks, the population contingent and the economic relevance of the region (MCTIC, 2014). In table 5, the quantity of PqTs existing in the host cities of the twelve Military Regions (table 4) are shown in order to demonstrate the potential of knowledge assets and the collaborative process of interorganizational governance.

Table 5. Technology parks in the headquarters of the Military Regions. (MCTIC, 2014 \& Endeavor Brazil, 2017).

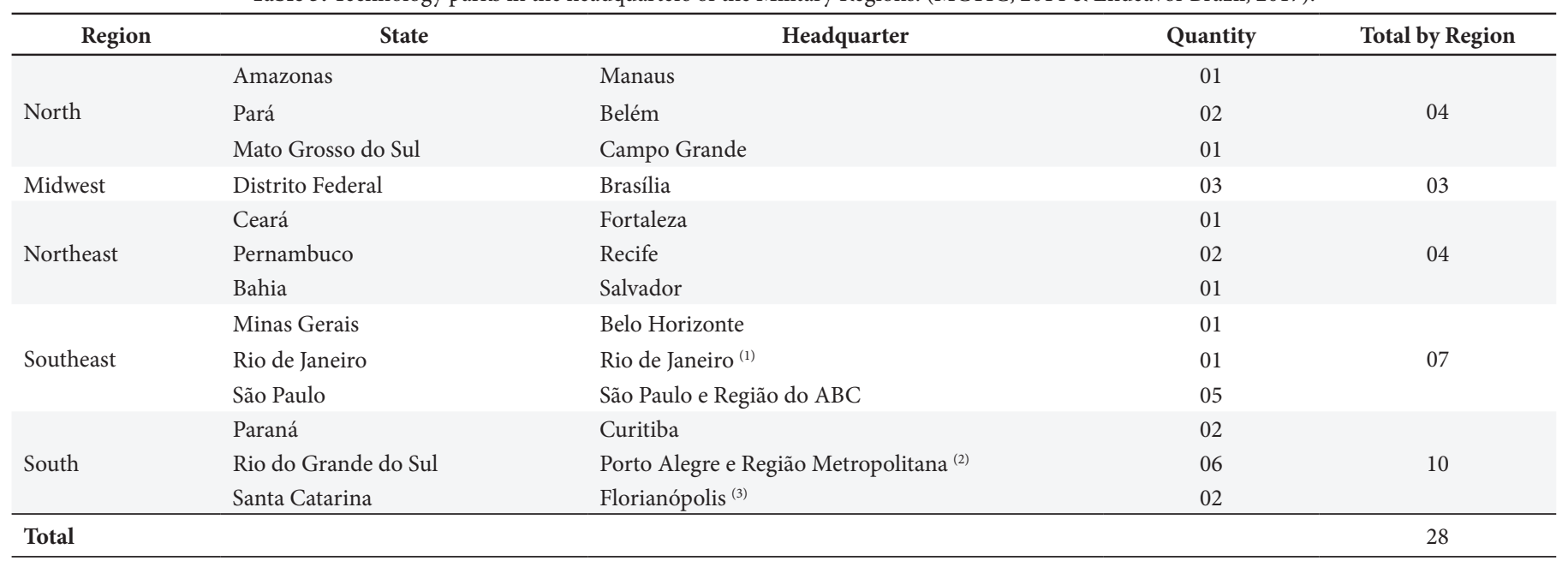

(1) Army Science and Technology Center in Guaratiba (PTEG).

(2) The municipalities of the Metropolitan Region of Porto Alegre that have TPs are Campo Bom, Canoas and São Leopoldo.

(3) It is not one of the headquarters of Military Region, but was considered in the year 2017, by the Index of Entrepreneurial Cities, Endeavor Brazil, the second most innovative city in the country. The methodology of the index is composed of the following factors: regulatory environment, infrastructure, market, and access to capital, innovation, human capital and entrepreneurial culture. In the Innovation factor, Florianópolis occupies the 3rd position in the research. 
The concentration of parks in the Southeast and South regions is a reflection of the economic, social, educational and innovation indicators of these geographical areas. However, according to MCTIC (2014), there is room for initiatives to implement and consolidate PqTs in the north, north-east and mid-west regions, which, in addition to using local potential, can also benefit of existing differentials for the transformation of knowledge into products, processes and services with high added value.

By investing in initiatives that aim to reduce the national dependence on external knowledge, as well as increasing the autochthonous capacity for innovation, the BA has sought to establish that the scientific and technological advances support the consolidation of the country as an emerging power in the international arena (Ministry of Defense, 2017).

From the point of view of national defense, the scientific and technological development is fundamental for achieving greater strategic autonomy and better operational capacity of the Armed Forces - especially in the three strategic sectors for National Defense - nuclear, cybernetic and space.

Thus, in order to illustrate the premise of the case of this research, it was delimited to analyze the case of IE of BA in the city of Curitiba, state of Paraná. In it, there is the Technopark, linked to the Pontifical Catholic University of Paraná (PUCPR), that is to say, one of the blades of the Triple-Helix (Academy), constituting a space dedicated to the transfer and development of new technologies.

At Technopark, it is possible to install technology-based companies, in particular the Research \& Development units. Its headquarters has a modern infrastructure of approximately $10.000 \mathrm{~m} 2$, and can be considered one of the most important technological hubs of Paraná and Brazil (Agência PUC, 2017).

Currently, there are 87 companies installed, generating approximately 16 thousand direct and indirect jobs, with investments totaling approximately R\$200 million. The Techno park Attraction Plan is composed of: i) institutional support and promotion network; ii) incentives for high-quality facilities for enterprises; iii) investments in marketing, connectivity and mobility; iv) strategic equipment offerings, supporting services, meeting and event centers; v) urban policy directed to the business sector; and vi) differentiated tax policy (Agência Curitiba, 2018).

In this way, the TechnoPark, linked to PUCPR, promotes the alignment with the various actors of society, either through the training and qualification of professionals, or through the production of research aligned with the needs of regional, state and national development.

In regard to Industry, the Federation of Industries of Paraná (FIEP), based in Curitiba, has been a promoting agent of the competitiveness of the industry from Paraná, acting as an integrator entity of the productive sector with the Academy, through actions promoted by the International Center of innovation (C2i).
Through FIEP it is possible to identify four major forces of interaction with the Brazilian Army: i) the expansion of the relationship between the industry of Paraná and the institution; ii) the identification and development of technologies and projects of interest for the formation of the Industrial Defense Base (IDB), in partnership with the Brazilian Association of Defense and Security Materials Industries (ABIMDE) and the Secretary of State for Industry, Commerce from Mercosul subjects, in Paraná (SEIM); iii) the induction and adaptations to the productive process of defense; and, iv) guarantee and institutional support in related demands.

\section{Proposed Structure of a Nucleus of Governance of Techno- logical Innovation for the Brazilian Army from the point of view of SisDIA}

Aligned with the objective of this research, the creation of a Nucleus of Governance of Technological Innovation of the Brazilian Army (NuGITEc BA), as shown in figure 3 , is suggested as an innovative proposal.

In this model, called collaborative governance, it is believed that it will be possible to foster and articulate the relationship between the various actors that belong to the innovation ecosystems at the headquarters of the Military Regions of the BA.

Specifically, in the case of Curitiba, the collaborative governance would be constituted from the perspective of the Triple-Helix by the - Government (5th Military Region Command) - Technopark (PUCPR) - Industry (FIEP), compounding the Nucleus of Governance of Technological Innovation of the Army (NuGITEc EB), with the purpose of leading and coordinating the collaborative process of implementation, consolidation and development of technology-based companies.

In collaborative governance it is essential to train leaders and the professionals who will work at the NuGITEcs in the process of innovation.

In this way, the nuclei can consolidate themselves as environments that aggregate the synergies of the elements of the Army Triple-Helix: Defense System, Industry and Academy (SisDIA).

Figure 3. Structure Model of the Nucleus of Governance of Technological Innovation of the Brazilian Army from the perspective of SisDIA. Author's elaboration.

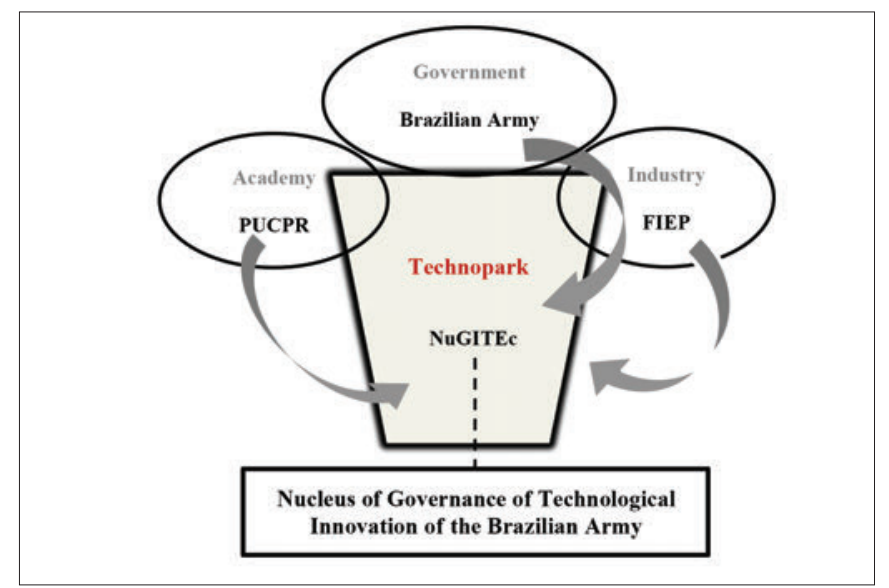


In this model (figure 3), the following possibilities stand out: the development of dual employment technology products (military and civil) integrated with the defense industrial base; support from research development agencies; coordination and implementation of municipal and regional public policies to promote the activity of defense industries; coordination and orientation for technological compensation agreements, by aligning actions and disseminating the practice among the agents of the sector; and, strengthening SisDIA's innovation and technology in the Brazilian Army, in the state of Paraná, and in other headquarters of the Military Regions.

At NuGITEc, it will be the Brazilian Army, under the planning and coordination of the Department of Science and Technology (DCT), that will play the role of articulator in the interaction of SisDIA, in order to lead and stimulate the creation of partnerships and the availability of resources to support the enterprises focused on the production of new technologies, so that the universities and institutes of science and technology may take the lead in a collaborative way, having the Army as a support for the entrepreneurial actions, with the training of human resources of the institution itself.

The challenges outlined in an economic and political scenario that imposes a number of uncertainties should serve as a driving force for the implementation of the NuGITEcs BA in order to enhance the strategic-operational capacity and the search for productive capacities of defense systems and dual technologies in the Brazilian states.

In regard to resources, NuGITEcs will have to play the role of mediator in obtaining public and private funding so that technology-based companies have access to the research carried out in the academy and, at the same time, these companies can produce the necessary materials to meet the demands of the Brazilian Army.

One of the challenges that persist on the part of the companies is the fear of innovating, often explained by the economic conjuncture and the low information on the types of investment and financing. It will therefore be the responsibility of the NuGITEcs to encourage the acquisition of sources of resources in order to promote potential for the CT\&I scenario at local and regional levels.

\section{Final considerations}

As presented in this study, the proposal of a structural model of a governance nucleus for the Brazilian Army, from the perspective of the Triple-Helix, possibly qualifies it as a consistent pilot project, in order to promote the interaction between Army-Industry-Academy, and generate innovation through the development of products strengthening the defense industrial base.

The collaborative governance model, inserted in the Technological Parks, aims to trigger actions and projects through the creation and implementation of technology-based companies and the achievement of the Brazilian Army's strategic objectives, through a process of modernization that is capable of promoting the constitution of a network of governance that establishes and disseminates the information and its demands.
The initiatives resulting from a formal and strategic planning, centered on the NuGITEcs, can attract consolidated companies and, at the same time, promote the creation of startups or accelerators in technological parks, thus contributing to social development and job and income generation.

The Technological Parks, located in the headquarters of the twelve Military Regions of the Brazilian Army, are thus innovative habitats capable of stimulating the economy based on knowledge, that intend to create an environment of synergy and trust between universities and companies, in order to increase the possibilities between knowledge assets in innovation ecosystems.

It is expected, therefore, that the NuGITEcs, besides reinforcing the scientific-technological expression of the actors involved, could potentiate regional economic expression with the expansion of opportunities arising from the commercialization of dual technology with high added value.

Given this context, it is suggested that the Brazilian Army Science, Technology and Innovation System (SCTIEx), through the NuGITEcs, seek a more autonomous relationship for the institutions involved, based on cooperation, trust, transparency and symmetry of the relations and, from this scenario, it can play the role of articulator either through the interaction between the various actors of the innovation ecosystem, or through sectorial public policies of innovation at the local and regional level, promoting, in a sustainable way, support to ensure and expand the proposed structural governance model.

Finally, in this study, developed in a seminal way, as a thesis project in the Post-Graduate Program in Administration (PUCPR), it allows the proposition of new studies that can identify the morphology of the proposed governance model in front of some scenarios, such as management of governance networks, identification and description of the responsibilities of each of the actors, as well as the mapping of collaborative processes that have produced innovative results.

\section{References}

Agência PUC. (2017). Tecnoparque. Available in: <http://www.agenciapuc.pucpr.br/tecnoparque.shtml>. Access in: Feb 17th, 2018.

Ansell, C. \& Gash, A. (2008). Collaborative governance in theory and practice. Journal of Public Administration Research and Theory, v. 18, p. 543-571. https://doi.org/10.1093/jopart/mum032

Bakouros, Y. L., Mardas, D. C., \& Varsakelis, N. C. (2002). Science park, a high tech fantasy? An analysis of the science parks of Greece. Technovation, n. 22, p. 123-128. https://doi.org/10.1016/S01664972(00)00087-0

Barbieri, J. C. (1995). Parques e incubadoras de base tecnológica: a experiência brasileira. Relatório ${ }^{\circ}$ 04. São Paulo: NPP/ FGV-EAESP, 1995. 
Brasil. (1977). Presidência da República Subchefia para Assuntos Jurídicos. Decreto no 79.813, de 14 de Junho de 1977. Aprova o Regulamento para os Grandes Comandos das Forças Terrestres (R/163) e dá outras providências. Available in: <http://www.planalto.gov.br/ccivil_03/decreto/1970-1979/D79813.htm>. Access in: Feb 20th, 2018.

Brasil. (1999). Presidência da República Subchefia para Assuntos Jurídicos. Decreto no 3.213, de 19 de Outubro de 1999. Dispõe sobre as áreas de jurisdição dos Comandos Militares de Área e das Regiões Militares no Exército Brasileiro, e dá outras providências. Available in: < https://www. planalto.gov.br/ccivil_03/decreto/d3213.htm>. Access in: Feb 20th, 2018.

Brasil. (2012). Ministério da Defesa. Exército Brasileiro. Departamento de Ciência e Tecnologia. Portaria n ${ }^{\circ} 032-\mathrm{DCT}$, de 11 de setembro de 2012. Aprova a Diretriz de Iniciação do Projeto de Transformação do Sistema de Ciência e Tecnologia do Exército. Boletim do Exército no 38/2012, Brasília, DF, 21 set. 2012. Available in: <http://www.sgex. eb.mil.br>. Access in: Feb 10th, 2018.

Brasil. (2013). Ministério da Defesa. Exército Brasileiro. Departamento de Ciência e Tecnologia. Estudo de Viabilidade Técnica e Econômica do Projeto do Polo de Ciência e Tecnologia do Exército em Guaratiba. Brasília, DF.

Brasil. (2018). Presidência da República. Casa Civil. Exército Brasileiro. Decreto no 9.283, de 7 de Fevereiro de 2018. Regulamenta a Lei da Inovação (Lei 10.973/2004). Available in: <http://www.planalto.gov. br/ccivil_03/_Ato2015-2018/2018/Decreto/D9283.htm>. Access in: March 2nd, 2018.

Bryson, J. M., Crosby, B. C. \& Stone, M. M. (2006). The design and implementation of crosssector collaboration: propositions from the literature abstract. Public Administration Review, n. December, p. 17-18. https://doi.org/10.1111/j.1540-6210.2006.00665.x

Buainain, A., Silveira, J. M. F. J. \& Marques, M. (1999). O Programa Cédula da Terra e a reorganização fundiária no Brasil. Campinas: IE/ Unicamp.

Cabral, S., Krane, D. \& Dantas, F. (2013). A dança dos blocos, empresários, políticos e técnicos: condicionantes da dinâmica de colaboração interorganizacional do carnaval de Salvador. Organizações \& Sociedade, v. 20, n. 64, p. 145-163. http://dx.doi.org/10.1590/S198492302013000100010

Carvalho, H. G., Cavalcante, M. B. \& Reis, D. R. (2009). Gestão da inovação: inovar para competir. Brasília: Sebrae.

Cassiolato, J. E. \& Lastres, H. (2003). O foco em arranjos produtivos e inovativos locais de micro e pequenas empresas. In: Cassiolato, J. E., Lastres, H. \& Maciel, M. L.(Comp.). Systems of innovation and development: Evidence from Brazil. Cheltenham, RU: Edward Elgar.

Departamento de Ciência e Tecnologia. DCT. (2017). Sobre a AGITEC. Available in: <http://www.dct.eb.mil.br/index.php/nu-agitec>. Access in: Feb 25th, 2018.
Departamento de Ciência e Tecnologia. DCT. (2018). SisDIA. Available in: <http://sisdia.dct.eb.mil.br/sisdia/assuntos/editoria-a/institucional/sisdia $>$. Access in: Feb 25th, 2018.

Endeavor Brasil. (2017). Índice de Cidades Empreendedoras - Brasil 2017. Relatório de pesquisa Endeavor Brasil - 2017/02. São Paulo.

Etzkowitz, Henry \& Leydesdorff, Loet. (2000). The dynamics of innovation: from national systems and "mode 2" to a triple helix of university-industry-government relations. Research Policy, n. 29, p. 109-123. https://doi.org/10.1016/S0048-7333(99)00055-4

Ferreira, V. G. (2015). Governança colaborativa na prática: uma análise das experiências nas APACs. 115f. Dissertação (Mestrado em Administração). Escola Brasileira de Administração Pública e de Empresas, Rio de Janeiro.

Hassink, Robert \& Hu, Xiaohui. (2012). From Specialisation to Diversification in Science and Technology Parks. World Technopolis Review, WTR, v. 1, p. 6-15, 2012.

International Association of Science Parks. IASP. (2010). Available in: <http://www.iasp.ws/publico/intro.jsp>. Access in: Feb 10th, 2018.

Labiak Junior, S. \& Gauthier, Fernando. (2010). RIS in the Brazilian Context: Innovation and Competitiveness leveraged by engineering and knowledge management. In: 27th IASP World Conference on Science \& Technology Park, IASP, Daejeon.

McGuire, M. (2006). Collaborative public managment: assessing what we know and how we know it. Public Administration Review, v. 66, p. 33-43. https://doi.org/10.1111/j.1540-6210.2006.00664.x

Ministério da Ciência, Tecnologia e Inovação. MCTI. (2014). Estudo de Projetos de Alta Complexidade: indicadores de parques tecnológicos. Centro de Apoio ao Desenvolvimento Tecnológico. Brasília: CDT/ $\mathrm{UnB}, 100 \mathrm{p}$.

Menezes, E. C. O. \& Vieira, P. H. F. (2011). Aglomeração industrial, governança e meio ambiente: conceitos e premissas da abordagem do desenvolvimento territorial sustentável. Revista Desenvolvimento e Meio Ambiente, n. 24, p. 101-118, jul./dez. Editora UFPR.

Ministério da Defesa. (2017). Ciência e Tecnologia. Available in: $<$ http://www.defesa.gov.br/ciencia-e-tecnologia>. Access in: Feb 10th, 2018.

Prado Filho, Hildo Vieira. (2014). A Transformação do Exército Brasileiro e o novo Sistema de Ciência, Tecnologia e Inovação do Exército: contribuições para a Soberania Nacional. 68f. Monografia (Escola Superior de Guerra). Rio de Janeiro: Escola Superior de Guerra (ESG).

Selsky, J. W. \& Parker, B. (2005). Cross-sector partnerships to address social issues: challenges to theoryand practice. Journal of Management, v. 31, n. 6, p. 849-873. https://doi.org/10.1177/0149206305279601 
Spinosa, L.M, Schlemm, M.M \& Reis, R. S. (2015). Brazilian innovation ecosystems in perspective: Some challenges for stakeholders. REBRAE, Curitiba, v. 8, n. 3, p. 386-400, sep./dec.

Storper, Michael \& Harrison, Bennett. (1991). Flexibility, hierarchy and regional developments: the changing structure of industrial production systems and their forms of governance in the 1990s. Research Policy, North-Holland, v. 20, n. 5, p. 407-422. https://doi. org/10.1016/0048-7333(91)90066-y
Suzigan, W. Furtado, J. \& Garcia, R. C. (2007). Estruturas de Governança em Arranjos ou Sistemas Locais de Produção. Gestão \& Produção (UFSCar), v. 14, p. 425-439. https://doi.org/10.1590/s0104530x2007000200017

Vergara, Sylvia Constant. (2004). Projetos e relatórios de pesquisa em Administração. São Paulo: Atlas. 